\title{
Effect of time of day for harvest and postharvest treatments on the sugar metabolism of broccoli (Brassica oleracea var. italica)
}

\author{
Joaquín Hasperué ${ }^{1,2}$, María Laura Lemoine ${ }^{1}$, Alicia Chaves ${ }^{1,2}$ and Gustavo Martínez ${ }^{2,3}$ \\ ${ }^{1}$ Centro de Investigación y Desarrollo en Criotecnología de Alimentos (CIDCA) CONICET-UNLP, calle 47 esquina 116, La Plata \\ (1900), Buenos Aires, Argentina \\ ${ }^{2}$ Facultad de Ciencias Exactas, Universidad Nacional de La Plata (UNLP), calle 47 esquina 115, La Plata (1900), Buenos Aires, \\ Argentina \\ ${ }^{3}$ Instituto de Investigaciones Biotecnológicas - Instituto Tecnológico de Chascomús (IIB-INTECH) UNSAM-CONICET, Camino \\ Circunvalación Laguna Km 6, Chascomús (B7130IWA), Buenos Aires, Argentina \\ e-mail: gmartinez@intech.gov.ar
}

\begin{abstract}
Loss of sugars contributes to accelerate postharvest senescence of broccoli. Several treatments have been developed to delay senescence, but in many cases their effects on sugar metabolism were not analyzed. We studied the effect of harvest at different times of day (08:00, 13:00 and 18:00 h) and of several postharvest treatments as heat treatment $(\mathrm{HT})$, modified atmosphere (MA) and 1-methylcylcopropene (1-MCP) on sugar levels and activities of enzymes related to sucrose and starch degradation. Harvesting at the end of day delayed the loss of chlorophylls and caused the lowest decrement in sugars, although no differences in invertase, sucrose synthase and $\beta$-amylase activities were detected among samples. Treatments of MA and 1-MCP caused a lower loss of glucose and fructose, while HT caused a lower decrement of sucrose. Treated samples maintained higher levels of chlorophylls. The treatments reduced the activity of invertase and sucrose synthase and induced higher levels of $\beta$-amylase activity. Harvesting at the end of day and performing simultaneously a MA treatment could be a good combination to maintain the green color of the inflorescence and sugar levels during postharvest of broccoli.
\end{abstract}

Key words: Invertase, sucrose synthase, $\beta$-amylase, senescence.

\section{Introduction}

Broccoli is a highly perishable vegetable with an elevated senescence rate. During postharvest, broccoli shows an intense degreening due to chlorophyll degradation. In addition, broccoli senescence is associated to a rapid loss of proteins and sugars (Pogson and Morris 1997, Eason et al. 2007). The level of sugars is important not only by its nutritional value but also by the physiological role that sugars have on senescence. Several reports have shown that treatments that delay the sugar loss (Carlin et al. 1990, Costa et al.2005, Lemoine et al. 2007) or treatments that feed with glucose or sucrose (Nishikawa et al. 2005, Hasperué et al. 2011) can delay postharvest senescence.

In broccoli, as in other higher plants, sucrose is the main source utilized to transport carbon. Inside the cells, sucrose is cleaved into glucose and fructose by two enzymes: sucrose synthase (SS) and invertase (INV). Invertase is considered to have a crucial role in regulating the transport and metabolism of sucrose in plants (Koch 1996). Invertases also have been associated with a role as a regulator of the amount of sucrose during senescence (Hurst et al. 1996, Coupe et al. 2003a, McKenzie et al. 2004, Eason et al. 2007).

SS catalyzes the reversible reaction of fructose and uridine diphosphate glucose (UDP-glucose) into sucrose. However, in many plant species it has been observed a lower Km values for UDP than for UDP-glucose, suggesting that the activity of SS is generally in the direction of sucrose hydrolysis rather than synthesis (Wind et al. 2010). Muñoz et al. (2005) assigned to SS an important role in the synthesis of transient starch in Arabidopsis thaliana leaves and Solanum tuberosum by channeling the UDP-glucose from sucrose to starch, decreasing the process in the night due to a fall in sucrose content. In photosynthetic tissues, starch accumulates transiently in chloroplasts during daylight hours by action of photosynthesis. However, for extended periods of photosynthesis, storage takes place in the amyloplasts in reserve tissues (Asatsuma et al. 2005). The transient starch is degraded releasing maltose and glucose units, which are then exported to the cytosol to be used as source of energy for synthesis of sucrose. Sugars derived from photosynthesis also are transported via phloem to target organs, where can be stored as starch reserves. Although $\alpha$-amylase has an important role in the degradation of starch in the endosperm of cereals (Asatsuma et al. 2005) it does not appear to have an essential role in arabidopsis leaves (Yu et al. 2005). The $\alpha$-amylase is required 
for the initiation of the degradation of the starch during the germination of grains, but is not required for normal degradation of transient starch in leaves. It is currently believed that the primary enzyme in starch degradation in the living tissue of the plant is the $\beta$-amylase enzyme (Yu et al. 2005, Zeeman et al. 2007, Orzechowski 2008). During the day, the starch is synthesized in chloroplasts by photosynthesis and is degraded during the subsequent night period (Zeeman et al. 2007). Among the enzymes involved in starch degradation, the $\beta$-amylase has a key role (Orzechowski 2008). Many reports show that high amounts of starch and sucrose increase the expression and activity of the $\beta$-amylase (Sharma and Shopfer 1987, Nakamura et al. 1991, Mita et al. 1995).

Most postharvest treatments in broccoli are aimed to delay senescence, taking the loss of green color as a primary quality parameter. In many cases, these treatments not only delay chlorophyll degradation but also maintain the level of sugars (Downs et al. 1997, Tian et al. 1997). The two methods more widely used are cooling (Rodrigues and Rosa 1999) and modified atmosphere (MA) (Makhlouf et al. 1989, Barth et al.1993). Treatment with controlled or modified atmosphere substantially reduces senescence, delaying chlorophyll degradation and decreasing respiratory activity (Barth et al. 1993, Coupe et al. 2003b). Also, it has been used 1-methylcyclopropene (1-MCP), a substance that blocks ethylene receptors, as post-harvest treatment (Fan and Mattheis 2000). 1-MCP reduces or inhibits synthesis of ethylene and its effects and retards the loss of chlorophyll by reducing its enzymatic catabolism (Gong \& Mattheis 2003). More recently other physical methods such as HT, UV-C and UV-B radiation as potential postharvest treatments have been under evaluation. These treatments cause a slight stress in the material without causing irreversible damage. The tissue can recover from stress and improves its performance against new stress situations. In broccoli, these treatments have been effective in delaying senescence, causing a lower degradation of chlorophylls and allowing the storage for longer time (Costa et al. 2006, Aiamla-or et al.2010, Martínez-Hernández et al. 2013). HT, can delay the onset of degradation of chlorophyll and slow down the senescence process (Funamoto et al. 2002, Costa et al. 2005). Also, broccoli treated with heat shows a lower loss of sucrose and proteins (Tian et al. 1997, Costa et al. 2005).

Postharvest life of horticultural products can be also affected by a range of preharvest factors. In broccoli, it was demonstrated that low water stress few days before harvest (Zaicovski et al. 2008) or harvesting at different moments at days (Hasperué et al. 2011) can affect senescence rate during postharvest.

Considering that the rate of senescence of broccoli is related to the level of sugars (Costa et al. 2005, Nishikawa et al. 2005, Eason et al. 2007), we proposed to study the effect of several treatments and the time of day at harvest on the content of sugars and the activity of enzymes involved in their metabolism: INV, SS and $\beta$-amylase during postharvest storage of broccoli.

\section{Materials and methods}

\section{Plant material}

Thirty heads of broccoli (Brassica oleracea var. Italica cv. 'Iron') were obtained from a farm on the outskirts of La Plata, Argentina ( $34^{\circ} 59^{\prime} \mathrm{S}$ and $58^{\circ} 3^{\prime} \mathrm{O}$ ) at each of the following times of day: 08:00 $\mathrm{h}, 13: 00 \mathrm{~h}$ and 18:00 $\mathrm{h}$, and transported immediately to the laboratory. Samples were placed in plastic trays and covered with PVC macro-perforated with 4 holes per tray, to prevent excessive dehydration. Broccoli heads were stored in darkness at $20^{\circ} \mathrm{C}$ during 4 days to accelerate senescence and ten heads were taken periodically, frozen with liquid nitrogen and subsequently stored at $-80^{\circ} \mathrm{C}$ until use.

\section{Postharvest treatments}

Following the traditional time of harvest, broccoli heads were harvested at 08:00 $\mathrm{h}$, transported immediately to the laboratory and subjected to the following treatments.

\section{Treatment with 1-MCP}

Thirty heads were placed in plastic trays and stored hermetically in a container with 1-MCP, and the condition of $1 \mu \mathrm{L} \mathrm{L}-1$-MCP for $16 \mathrm{~h}$ at $22{ }^{\circ} \mathrm{C}$ was the most effective to slow the yellowing. Thirty heads were used as controls and placed in the same conditions without 1-MCP. 
J. Hasperué et al. (2014) 23: 48-59

Heat treatments $(\mathrm{HT})$

Thirty heads were placed on trays, covered with macro-perforated polyvinyl chloride (PVC) film to reduce dehydration and put into a convection air oven at $42{ }^{\circ} \mathrm{C}$ for $3 \mathrm{~h}$. The same number of heads without heating was utilized as controls.

\section{Treatment with MA}

Thirty heads were placed in plastic trays, covered individually in low density polyethylene (LDPE) bags (40 $\mu \mathrm{m}$ thick, $20 \mathrm{~cm} \times 30 \mathrm{~cm}$ ) and then sealed. Gas composition inside the bags was measured as indicated in Costa et al. (2005). The same number of heads was coated with macro-perforated PVC film as a control.

After treatments the heads were stored in darkness at $20^{\circ} \mathrm{C}$ and processed as described in the preceding paragraph.

\section{Superficial color}

The superficial color ( $\left.L^{*} a^{*} b^{*}\right)$ was measured with a colorimeter (Minolta CR-400, Osaka, Japan) during the storage period. Reflectance was measured in different sectors of the inflorescence, taking 6 data per head. Hue angle $\left(h^{\circ}\right)$ was calculated as:

$\mathrm{h}^{\circ}=\tan ^{-1}(-(b / a))$ when $a$ and $b>0$, or

$\mathrm{h}^{\circ}=180^{\circ}+\tan ^{-1}(b / a)$ when $a<0$ and $b>0$.

\section{Chlorophyll content}

The chlorophyll content was determined as Lemoine et al. (2007) with slight modifications. Frozen samples were ground with an electric grinder. Then, approximately $0.8 \mathrm{~g}$ of the powder were mixed with $5 \mathrm{ml} 80 \%(\mathrm{v} / \mathrm{v})$ acetone, homogenized and centrifuged at $5000 \mathrm{xg}$ for $10 \mathrm{~min}$. The supernatant was removed and the pellet was suspended in $3,750 \mu \mathrm{l}$ of $80 \%(\mathrm{v} / \mathrm{v})$ acetone and centrifuged at 5,000 xg for $10 \mathrm{~min}$. Finally, the pellet was suspended again in $1,250 \mu \mathrm{l}$ of $80 \%(\mathrm{v} / \mathrm{v})$ acetone and centrifuged at 5,000 xg for $5 \mathrm{~min}$. Supernatants from each centrifugation were collected and kept to a final volume of $10 \mathrm{ml}$ with $80 \%(\mathrm{v} / \mathrm{v})$ acetone. Chlorophyll content was determined according to Lichtenthaler (1987) and expressed as $\mathrm{mg}$ total chlorophyll $\mathrm{g}^{-1} \mathrm{FW}$ tissue. Four extracts per treatment and storage time were obtained and measurements were done by triplicate.

\section{Sucrose, glucose and fructose determination}

Frozen broccoli florets were ground in a refrigerated mill and $2 \mathrm{~g}$ of the obtained powder were homogenized with $12 \mathrm{ml}$ of ethanol. The mixture was centrifuged at $12000 \mathrm{xg}$ for $15 \mathrm{~min}$ at $4{ }^{\circ} \mathrm{C}$ and the supernatant was recovered to determine the content of sugars. The ethanol extract was filtered through a nylon filter of $0.45 \mu \mathrm{m}$ pore size and the solvent evaporated by heating. The sample was dissolved in a mixture of acetonitrile:water 70:30. Concentration of soluble sugars was determined by using a high-pressure liquid chromatography system equipped with a refractive index detector (Waters IR 2414, Waters Corp., USA) and a Microsorb-MV NH${ }_{2}$ R0086700C5 column (Varian Inc., USA). The column was isocratically eluted with acetonitrile:water 70:30 at a rate of $1 \mathrm{ml} \mathrm{min}^{-1}$. Four extracts per treatment and storage time were obtained and measurements were done by triplicate. The results were expressed in $\mathrm{mg}$ sugar $\mathrm{g}^{-1} \mathrm{FW}$.

\section{Enzyme extractions and assays}

Soluble acid INV was extracted and assayed as detailed in Coupe et al. (2003a), with the modifications: 2 g of ground samples were suspended with $10 \mathrm{ml}$ of ice-cold extraction buffer ( $25 \mathrm{mM}$ Hepes- $\mathrm{NaOH}$ pH 7.5 containing PVPP $1 \% \mathrm{w} / \mathrm{v}, 4 \mathrm{mM}$ EDTA, $10 \mathrm{mM}$ cysteine, $10 \mathrm{mM} \mathrm{MgCl}$ ). The homogenate was allowed to stir for $30 \mathrm{~min}$ at $4{ }^{\circ} \mathrm{C}$, and then centrifuged at $13200 \mathrm{xg}$ in cold for $10 \mathrm{~min}$. The supernatant was separated and utilized for assaying acid INV. A volume of $0.2 \mathrm{ml}$ of supernatant was mixed with $0.4 \mathrm{ml}$ of $25 \mathrm{mM}$ sucrose, $50 \mathrm{mM}$ sodium acetate $\left(\mathrm{pH} \mathrm{6.0)}\right.$ and the resulting solution was maintained at $35^{\circ} \mathrm{C}$ for $30 \mathrm{~min}$. The generated glucose was measured enzymatically (glucose oxidase $10 \mathrm{U} \mathrm{ml}^{-1}$ and peroxidase $1 \mathrm{U} \mathrm{ml}^{-1}$ ) with a glucose test kit (Wiener Lab). 
J. Hasperué et al. (2014) 23: 48-59

$\beta$-amylase was extracted by suspending $2 \mathrm{~g}$ of ground samples with $5 \mathrm{ml}$ of ice-cold extraction buffer (Tris-EDTA $\mathrm{pH} 8.0$ with $100 \mathrm{mM}$ cysteine). Homogenate was maintained during $1 \mathrm{~h}$ in cold and agitation, and then centrifuged at $13200 \mathrm{xg}$ for $10 \mathrm{~min}$. The supernatant was recovered and $0.2 \mathrm{ml}$ were diluted with $0.6 \mathrm{~mL}$ of dilution buffer $(0.1$ M MES, $1 \mathrm{mM}$ EDTA, $1 \mathrm{~g}^{-1}$ bovine serum albumin, $\mathrm{pH}$ 6.2). The enzyme activity was measured according to the kit Betamyl Method (Megazyme International Ireland Ltd).

SS was extracted as described for acid invertase. The homogenate was allowed to stir for 40 min at $4{ }^{\circ} \mathrm{C}$, and then centrifuged at $13200 \mathrm{xg}$ for $10 \mathrm{~min}$. The supernatant was assayed for SS cleavage activity as described by Sowokinos et al. (1985), with modifications. Briefly, $0.14 \mathrm{ml}$ extract, $5 \mathrm{mM}$ UDP in $50 \mathrm{mM}$ Hepes buffer (pH 7.5) and $120 \mathrm{mM}$ sucrose. The mixture was incubated at $35^{\circ} \mathrm{C}$, samples were taken periodically and reactions were stopped by heating tubes in a boiling water bath for $5 \mathrm{~min}$. The production of reducing sugars was determined by the DNS method (Miller 1959).

The enzyme activities were expressed as units relative to the value obtained in samples harvested at $08: 00 \mathrm{~h}$ for the experiments of the different moments of harvest during the day or in units relative to day 0 (day of harvest) for MA, HT and 1-MCP treatments. Four extracts per treatment and storage time were obtained and measurements of activity were done by triplicate.

\section{Experimental design and statistical analysis}

The whole experiment was repeated three times and designed according to a factorial design, the factors being time of harvest or postharvest treatment and storage time. All statistical procedures were performed by using the SYSTAT software package. The results were analyzed by ANOVA and means were compared using LSD test at significance level of 0.05 .

\section{Results and discussion Harvesting at different times of the day Chlorophyll and sugar contents}

Broccoli heads were harvested at different times of the day and stored. The progress of senescence was followed by measuring superficial color and chlorophyll content (Table 1).

Table 1. Changes in Hue values and chlorophyll contents ( $\mathrm{mg} \mathrm{chl} \mathrm{g}^{-1} \mathrm{FW}$ tissue) in broccoli florets harvested at different hours (08:00, 13:00 and 18:00 h) and stored during four days at $20^{\circ} \mathrm{C}$.

\begin{tabular}{ccccccc}
\hline & \multicolumn{3}{c}{ Hue } & & \multicolumn{3}{c}{ Chlorophyll } \\
& $08: 00 \mathrm{~h}$ & $13: 00 \mathrm{~h}$ & $18: 00 \mathrm{~h}$ & $08: 00 \mathrm{~h}$ & $13: 00 \mathrm{~h}$ & $18: 00 \mathrm{~h}$ \\
\hline Day 0 & $131.2 \pm 2.8^{\mathrm{a}}$ & $130.3 \pm 3.8^{\mathrm{a}}$ & $129.7 \pm 2.0^{\mathrm{a}}$ & $0.299 \pm 0.020^{\mathrm{a}}$ & $0.292 \pm 0.021^{\mathrm{a}}$ & $0.295 \pm 0.019^{\mathrm{a}}$ \\
Day 2 & $126.2 \pm 1.6^{\mathrm{a}}$ & $128.3 \pm 2.2^{\mathrm{b}}$ & $129.2 \pm 2.5^{\mathrm{b}}$ & $0.207 \pm 0.009^{\mathrm{a}}$ & $0.250 \pm 0.018^{\mathrm{b}}$ & $0.271 \pm 0.018^{\mathrm{c}}$ \\
Day 4 & $109.1 \pm 1.5^{\mathrm{a}}$ & $117.8 \pm 2.3^{\mathrm{b}}$ & $123.4 \pm 1.4^{\mathrm{c}}$ & $0.101 \pm 0.015^{\mathrm{a}}$ & $0.129 \pm 0.013^{\mathrm{b}}$ & $0.170 \pm 0.011^{\mathrm{c}}$ \\
\hline
\end{tabular}

Different letters indicate significant differences $(p<0.05)$ among samples at the same time of storage.

At harvest, all samples had a dark green color and similar Hue values and chlorophyll content. During storage, samples lost their green color and became yellow but these changes were more marked in samples harvested at 08:00 h. In turn, samples obtained at 18:00 h showed the lowest Hue decrement and chlorophyll degradation, having about $68 \%$ more chlorophylls than heads harvested at 08:00 h. These results were similar to those obtained in our previous work (Hasperué et al. 2011).

Besides the loss of green color and chlorophyll degradation, the normal postharvest physiology of broccoli is characterized by a rapid loss of sucrose (Downs et al. 1997, Tian et al. 1997, McKenzie et al. 2004). It has been proposed that a decrease in the level of sugars would in turn increase the expression of senescence-associated genes, such as ACC oxidase, $\beta$-galactosidases and asparagine synthetases (Downs et al. 1997). 
J. Hasperué et al. (2014) 23: 48-59

In this work, sugars were measured by HPLC and a decrease of their contents was detected during the postharvest period in all samples. At harvest, there were no differences in sugar contents among samples harvested at different times. However, differences were detected during storage, so that the samples harvested at 18:00 h showed the lowest decrement (Fig. 1). We found a higher level of starch in samples harvested at 18:00 h (data not shown) as we had detected previously (Hasperué et al. 2011). The highest content of glucose in these samples both at day 2 and 4 could be due to the rapid hydrolysis of starch that occurs after harvest (King and Morris 1994, Tian et al. 1997, McKenzie et al. 2004).

Regarding the content of sucrose, at day 2, samples harvested at 13:00 h and 18:00 h showed higher levels about 115 and $200 \%$ more than samples harvested at 08:00 h, and at day 4 the content of sucrose was 100 and $250 \%$ higher, respectively. The content of glucose and fructose in samples harvested at 08:00 $\mathrm{h}$ was similar to samples of 13:00 $\mathrm{h}$ and 18:00 $\mathrm{h}$ at day 0 , which could have been due to the contribution of the hydrolysis of sucrose in the early hours of the morning. Towards day 4, samples harvested at 13:00 h and 18:00 h maintained 25 and $35 \%$ more fructose and $52 \%$ of glucose than the samples harvested at 18:00 $\mathrm{h}$.

\section{Enzymatic activities}

At harvest, INV activity of samples harvested at 13:00 $\mathrm{h}$ and 18:00 $\mathrm{h}$ was 25 and $40 \%$ higher compared to activity of samples from 08:00 h (Fig. 2a). Similar behavior was described by Nägele et al. (2010) in Arabidopsis, which reported a diurnal fluctuation with maximum activity around 13:00 $\mathrm{h}$ but decreased until the end of the night. It was shown that INV activity could be enhanced by external applications of sucrose (Da Silva et al. 2003). In this sense, the higher INV activity in samples harvested at 18:00 h could be due to a higher content of sucrose in these samples. INV activity decreased during storage in all samples, and while the sucrose content also decreased, it remained higher in materials harvested at 13:00 $\mathrm{h}$ and 18:00 h, but without differences in invertase activity among samples (Fig. 2a).

At harvest, SS activity was almost $40 \%$ higher in samples harvested at $18: 00 \mathrm{~h}$ in relation to others (Fig. 2b). One of the roles of SS is the cleavage of sucrose that provides UDP-glucose which can be used both in the process of cell wall biosynthesis and in starch synthesis (Martin et al. 1993, Wang et al. 1993, Muñoz et al. 2005). Given this last association, the higher levels of starch found in broccoli harvested at 18:00 h (Hasperué et al. 2011) could be related to the higher SS activity in these materials at harvest. During storage, it was observed a decrease in SS activity in all samples, a result expected given the decline in the reserve of photoassimilates. In spite that samples of 18:00 h had higher sucrose levels until day 4, and starch until day 2 (data not shown, published in Hasperué et al. 2011), towards the end of the storage there was no difference in the SS activity among samples (Fig. 2b). The higher content of sucrose and other soluble in samples harvested at 18:00 $\mathrm{h}$ could be due to higher initial starch and its subsequent degradation rather than to lower levels of SS and INV activities.

At harvest, it was found that the $\beta$-amylase activity was $30 \%$ higher in samples of $18: 00 \mathrm{~h}$ comparing to the other harvest times. At harvest, samples obtained at 18:00 h had higher levels of starch (data not shown, published in Hasperué et al. 2011), probably due to the longer exposition to light with respect to the samples harvested at 08:00 h or 13:00 h (Smith et al. 2004, Bläsing et al. 2005). Given that the starch degradation is regulated by the circadian rhythm (Lu et al. 2005), this higher level of starch also could induce a higher $\beta$-amylase activity.

During the subsequent days of storage, it was detected a gradual decrease in the $\beta$-amylase activity in all samples, but this trend was less marked in those harvested at 13:00 h. After 2 days storage, all samples had the same activity, and toward the day 4 the enzyme activity was greater in samples harvested at 13:00 and 18:00 h, even though the broccoli has undetectable starch levels (Tian et al. 1997, Hasperué et al. 2011). 


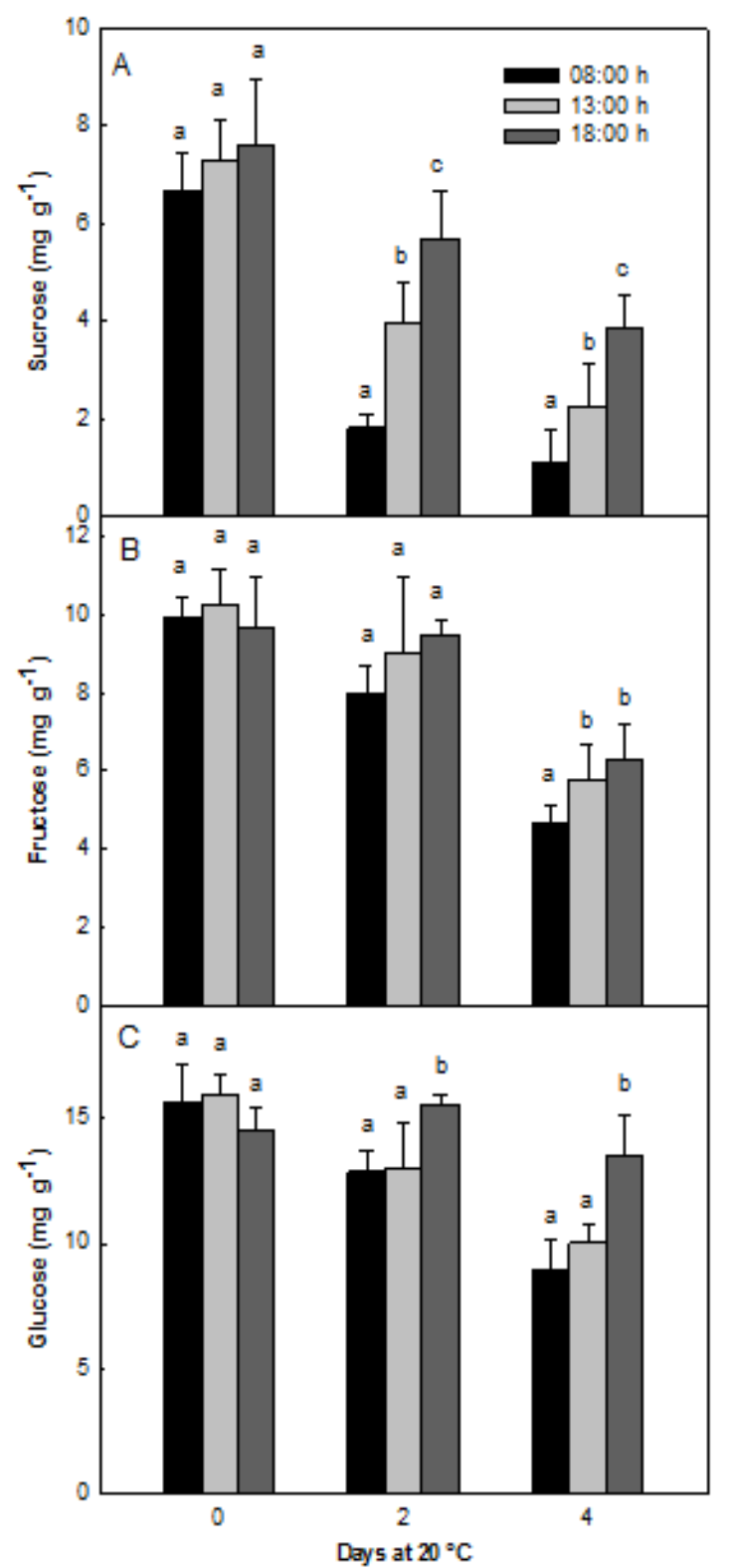

Fig. 1. Content of soluble sugars: sucrose (A), fructose (B) and glucose $(\mathrm{C})$ in broccoli florets harvested at different hours of the day during storage at $20^{\circ} \mathrm{C}$. Different letters indicate significant differences at the same time of storage $(p<0.05)$.

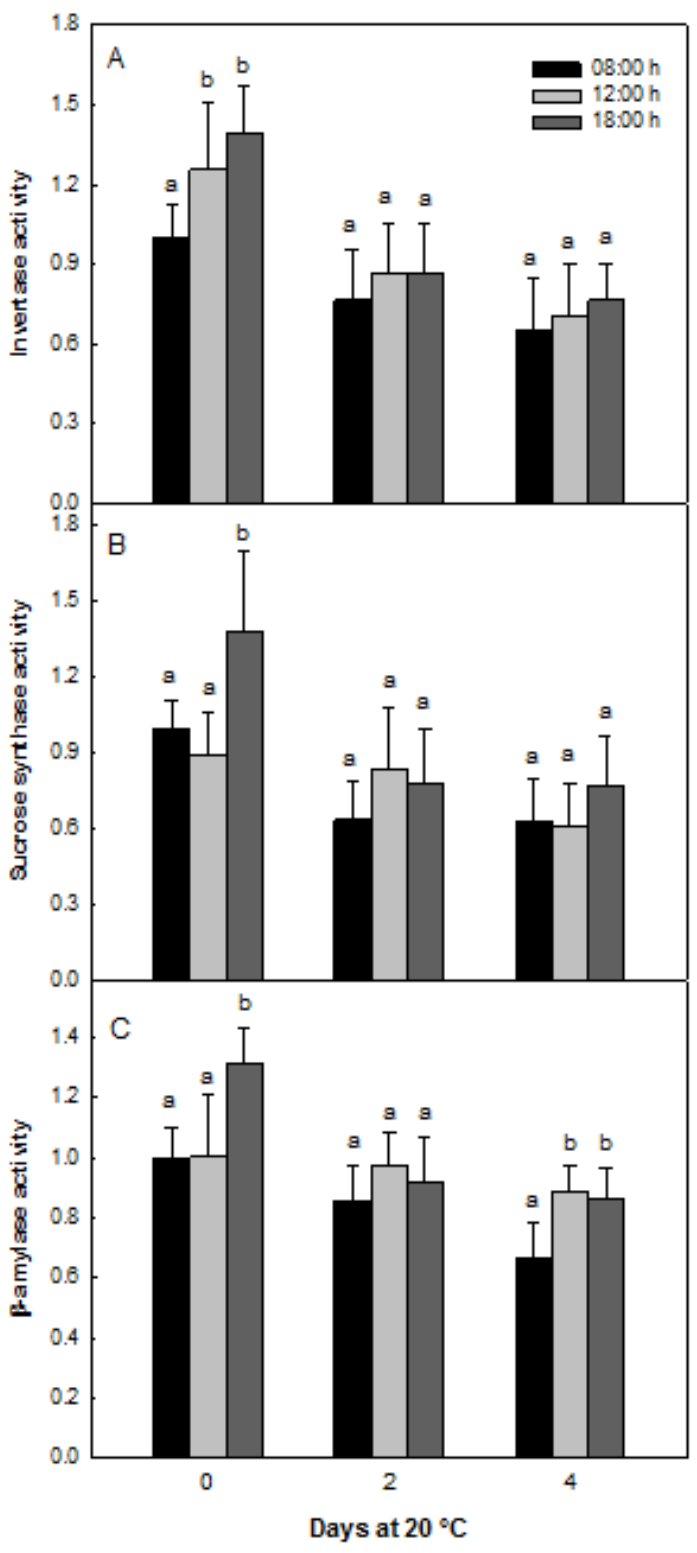

Fig. 2. Activity of invertase (A), sucrose synthase (B) and $\beta$-amylase $(C)$ in broccoli florets harvested at different hours of the day during storage at $20^{\circ} \mathrm{C}$. Activities are expressed as units relative to the value obtained in samples harvested at 08:00 h. Different letters indicate significant differences at the same time of storage $(p<0.05)$. 


\section{Postharvest treatments \\ Superficial color and chlorophyll and sugar contents}

After harvest, samples were subjected to three types of treatments: MA, HT, and application of 1-MCP. We checked the effectiveness of MA treatment by measuring the gas composition inside the bags. We found concentrations of about $7 \% \mathrm{O}_{2}$ and $8 \% \mathrm{CO}_{2}$ after two days and $5 \% \mathrm{O}_{2}$ and $10 \% \mathrm{CO}_{2}$ after four days of storage. Samples used as controls deteriorated rapidly, beginning to lose the green color and degrading chlorophylls from the second day of storage (Table 2). There was a smaller decline in Hue angle and chlorophyll degradation in those samples subjected to the three postharvest treatments (MA, HT, and 1-MCP), being MA the most effective in maintaining the visual qualities of broccoli.

Table 2. Changes in Hue values and chlorophyll contents (mg chlorophyll g-1 $\mathrm{FW}$ tissue) in broccoli florets subjected at different postharvest treatments and stored during four days at $20^{\circ} \mathrm{C}$. Different letters indicate significant differences $(p<0.05)$ among samples at the same time

\begin{tabular}{|c|c|c|c|c|c|c|c|c|}
\hline & \multicolumn{4}{|c|}{ Hue } & \multicolumn{4}{|c|}{ Chlorophyll } \\
\hline & Control & MA & HT & 1-MCP & Control & MA & HT & 1-MCP \\
\hline Day 0 & $125.7 \pm 2.8^{\mathrm{a}}$ & $125.7 \pm 2.8^{\mathrm{a}}$ & $125.7 \pm 2.8^{\mathrm{a}}$ & $125.7 \pm 2.8^{\mathrm{a}}$ & $0.267 \pm 0.020^{\mathrm{a}}$ & $0.267 \pm 0.020^{\mathrm{a}}$ & $0.267 \pm 0.020^{a}$ & $0.267 \pm 0.020^{\mathrm{a}}$ \\
\hline Day 2 & $119.6 \pm 1.8^{\mathrm{a}}$ & $126.7 \pm 2.0^{\mathrm{b}}$ & $124.9 \pm 1.8^{b}$ & $126.3 \pm 2.2^{b}$ & $0.180 \pm 0.012^{\mathrm{a}}$ & $0.216 \pm 0.015^{b}$ & $0.205 \pm 0.017^{b}$ & $0.237 \pm 0.020^{\circ}$ \\
\hline Day 4 & $101.9 \pm 1.7^{\mathrm{a}}$ & $120.6 \pm 2.5^{b}$ & $121.4 \pm 3.8^{b}$ & $122.3 \pm 3.0^{\mathrm{b}}$ & $0.086 \pm 0.017^{a}$ & $0.210 \pm 0.018^{b}$ & $0.197 \pm 0.015^{b}$ & $0.172 \pm 0.012^{\circ}$ \\
\hline
\end{tabular}

Loss of chlorophyll may be initiated or accelerated when plant tissue is exposed to low levels of ethylene. Accordingly, the elevated $\mathrm{CO}_{2}$ atmosphere inside the packages may have prevented accumulation of higher levels of ethylene, by competitive inhibition (Burg and Burg 1969). the HT samples exhibited similar behavior, which may have been due to a reduction in the activity of enzymes and expression of genes involved in ethylene biosynthesis and chlorophyll degradation (Funamoto et al. 2002, Suzuki et al. 2005, Costa et al. 2006, Büchert et al. 2011). In samples subjected to 1-MCP treatment chlorophyll content decreased towards day 4. As in the case of HT, the 1-MCP treatment reduces activity of enzymes involved in ethylene biosynthesis and in chlorophyll degradation (Tian et al. 1997, Gong and Mattheis 2003, Gómez-Lobato et al. 2012).

The process of senescence is accompanied by a high energy consumption that leads to a decrease in the content of simple sugars and starch. Postharvest treatments that delay the senescence process generally decrease the respiratory activity (Tian et al. 1997, Funamoto et al. 2002, Coupe et al. 2003b) and allow the product to maintain a higher level of sugars. In our study, the content of fructose, glucose and sucrose decreased towards day 4 in all samples, as it was described in other cases, too (King and Morris 1994, Downs et al. 1997, Pramanik et al. 2005, Baclayon and Matsui 2009). In general, the controls showed a more pronounced decline until day 4 (Fig. 3). That drop in sugars is probably due to the need of tissues to maintain the energy status during senescence (King and Morris 1994). Materials subjected to MA, HT and 1-MCP showed a delay in the loss of soluble sugars, even augmenting about 38\% sucrose between day 2 and 4 and 15\% fructose levels in MA and 13\% glucose in 1-MCP treated samples. At day 2, HT samples exhibited similar values of glucose and fructose and a higher level of sucrose in relation to controls, maintaining these differences at day 4. After two days of storage, MA and 1-MCP samples had 44 and $28 \%$ more glucose, about $35 \%$ more fructose but similar levels of sucrose in relation to controls. However, after four days, these samples and those subjected to HT showed higher levels of glucose, fructose and sucrose than controls. 


\section{Enzymatic activities}

A decrease in the sucrose content after harvest is one of the key signaling events that control the expression of genes during senescence, and this decrease was associated with the increase of INV activity (Coupe et al. 2003a). We measured the activity of saccharolytic enzymes (INV and SS), and of $\beta$-amylase in samples subjected to the different treatments during storage at $20^{\circ} \mathrm{C}$.

In all samples, INV activity decreased during storage, being the controls and samples treated with 1-MCP which maintained higher levels, while samples subjected to MA and HT showed a lower INV activity (Fig. 4a). Several studies have shown that the expression of genes encoding INV increases during senescence of broccoli (Coupe et al. 2003a, Pramanik et al. 2004, Eason et al. 2007). However, other studies have shown that the activity rises after harvest and then shows a fall during this period (McKenzie et al. 2004, Suthumachai et al. 2006).

It was reported that treatment with MA causes a reduction in the accumulation of transcripts of genes of INV (Coupe et al. 2003a). INV activity was also 62 and 73\% lower at day 2 and 4 of storage in HT samples. Last fact could be due to the sensitivity of INV to stress produced by the high temperatures (Singh and Knox 1984, Cheikh and Jones 1995). In the case of samples treated with 1-MCP, INV activity was similar to that of controls (Fig. 4a). Although in Solanum lycopersicum and Pyrus pyrifolia, it has been described that the ethylene would have a positive effect on the expression and activity of INV (Jeffery et al. 1984, Itai and Tanahashi 2008), in this assay there were no appreciable changes in INV activity in samples treated with 1-MCP, suggesting that, in broccoli, ethylene plays a minor role in INV activity or that treatment with 1-MCP was ineffective in reducing even more its activity.

SS activity decreased during storage in all samples, but the decrement was more important in treated samples (Fig. 4b). However, HT samples showed the lowest levels of activity, which could be to the influence of this treatment in the depression of the enzymatic metabolism (Wang et al. 1993).

The $\beta$-amylase activity decreased in both treated and control samples, from the day 0 to 2 , with no differences among samples. Toward the day $4, \beta$-amylase activity decreased in controls, increased in materials subjected to MA and maintained in HT samples or 1-MCP. As a consequence, $\beta$-amylase activity in controls was an average $50 \%$ lower than HT and 1-MCP and a half respect to MA samples (Fig. 4c).

Tissues during senescence or subjected to any kind of stress, have an increased demand of hexoses, which can be obtained through hydrolysis of sucrose in a reaction mediated by INV and SS, or by starch degradation catalyzed by $\beta$-amylase (Sturm and Chrispeels 1990). In our case, a deceleration in the senescence process by HT, MA or 1-MCP could reduce INV and SS activity even more. The lower levels of combined INV and SS activity and higher levels of $\beta$-amylase in treated samples could be reflected by a higher content of sucrose, fructose and glucose in these samples. 


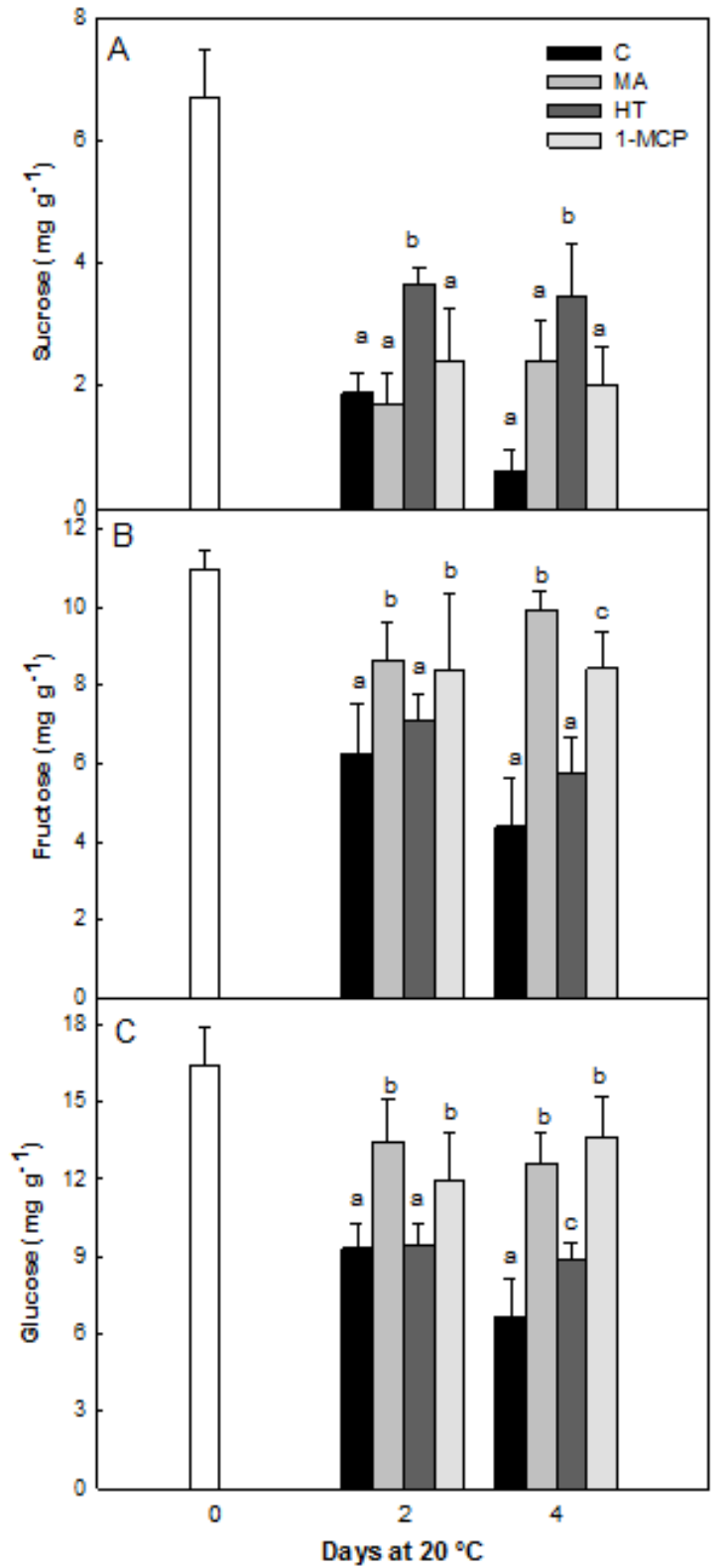

Fig. 3. Content of soluble sugars: sucrose (A); fructose (B); and glucose $(C)$ in broccoli heads subjected to different postharvest treatments: control (C), modified atmosphere (MA), heat treatment (HT) and 1-methylcyclopropene (1$\mathrm{MCP}$ ). Different letters indicate significant differences at the same time of storage $(p<0.05)$.

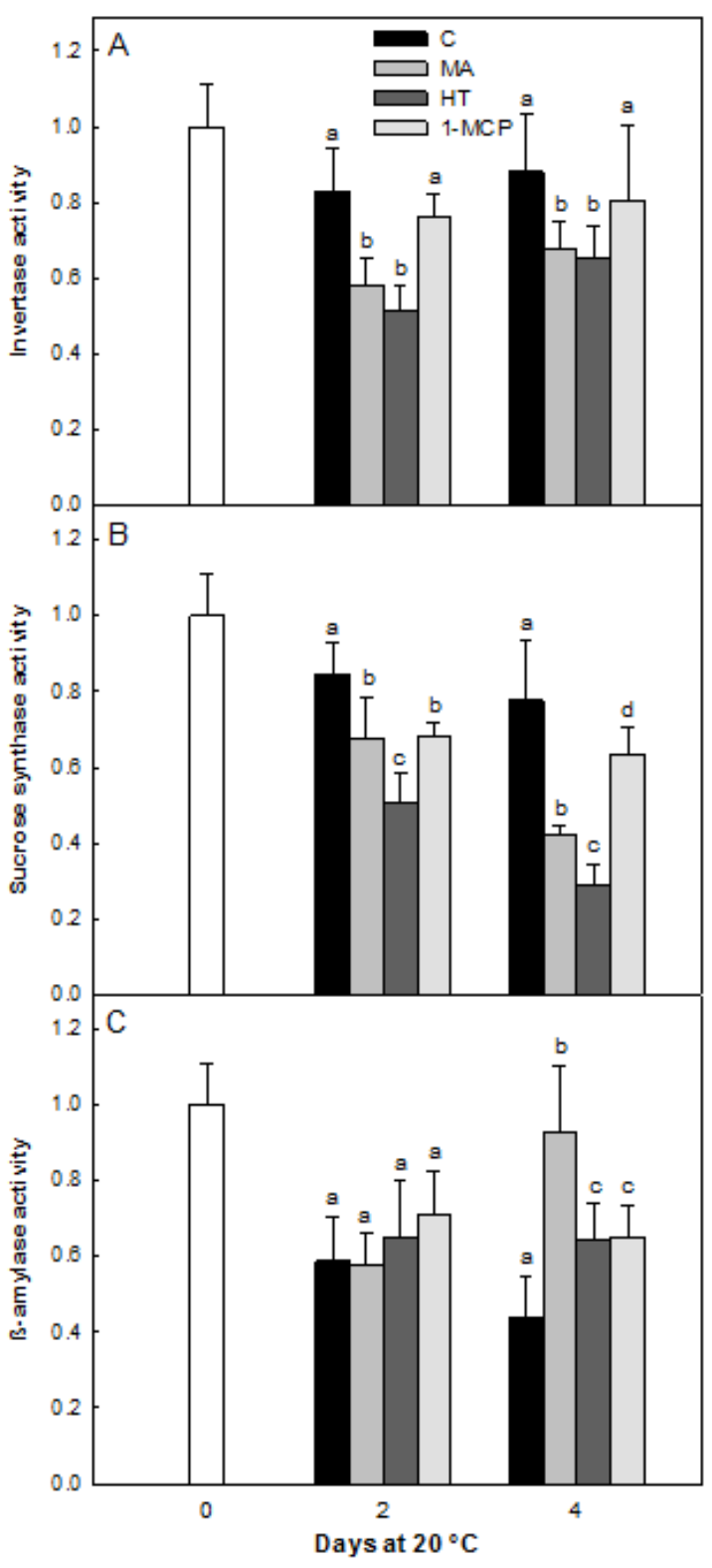

Fig. 4. Activity of invertase (A), sucrose synthase (B) and $\beta$-amylase (C) inbroccoli heads subjected to different postharvest treatments: control (C), modified atmosphere (MA), heat treatment (HT) and 1-methylcyclopropene (1$M C P)$. Different letters indicate significant differences at the same time of storage $(p<0.05)$.

\section{Conclusions}

Since samples harvested at 18:00 $\mathrm{h}$ and those treated with MA, HT and 1-MCP in general maintained higher levels of sugars, which also resulted in a greater Hue parameter and a higher retention of chlorophylls, those could be used to extend the postharvest shelf life of broccoli. 


\section{Acknowledgments}

This work was based on funding from Agencia Nacional de Promoción Científica y Tecnológica (Argentina) PICT2007-01120.

\section{References}

Aiamla-or, S., Kaewsuksaeng, S., Shigyo, M. \& Yamauchi N. 2010. Impact of UV-B irradiation on chlorophyll degradation and chlorophyll-degrading enzyme activities in stored broccoli (Brassica oleracea L. Italica Group) florets. Food Chemistry 120: 645-651.

Asatsuma, S., Sawada, C., Itoh, K., Okito, M., Kitajima, A. \& Mitsui, T. 2005. Involvement of $\alpha$-amylase I-1 in starch degradation in rice chloroplasts. Plant and Cell Physiology 46: 858-869.

Baclayon, D.P. \& Matsui, T. 2009.Carbohydrate status of sucrose-fed broccoli head during storage and the activity and gene expression of sucrose synthase. Annals of Tropical Research 31: 34-46.

Barth, M.M., Kerbel, E.L., Perry, A.K. \& Schmidt S.J. 1993. Modified atmosphere packaging affects ascorbic acid, enzyme activity and market quality of broccoli. Journal of Food Science 58: 140-143.

Bläsing, O.E., Gibon, Y., Günther, M., Höhne, M., Morcuende, R., Osuna, D., Thimm, O., Usadel B., Scheible, W.R. \& Stitt, M. 2005. Sugars and circadian regulation make major contributions to the global regulation of diurnal gene expression in arabidopsis. Plant Cell 17: 3257-3281.

Büchert, A.M., Civello, P.M. \& Martínez, G.A. 2011. Effect of hot air, UV-C, white light and modified atmosphere treatments on expression of chlorophyll degrading genes in postharvest broccoli (Brassica oleracea L.) florets. Scientia Horticulturae 127: $214-219$.

Burg, S.\& Burg, E.A. 1969. Interaction of ethylene, oxygen and carbon dioxide in the contro1 of fruit ripening. Qualitas Plantarum et Materiae Vegetabiles 19: 185-200.

Carlin, F., Nguyen-The, C., Chambroy, Y. \& Reich, M. 1990. Effects of controlled atmospheres on microbial spoilage, electrolyte leakage and sugar content of fresh 'ready-to-use' carrots. International Journal of Food Science and Technology 25: 110-119.

Cheikh, N. \& Jones, R.J. 1995. Heat stress effects on sink activity of developing maize kernels grown in vitro. Physiologia Plantarum 95: 59-66.

Costa, M.L., Civello, P.M., Chaves, A.R. \& Martínez, G.A. 2005. Effect of hot air treatments on senescence and quality parameters of harvested broccoli (Brassica oleracea L. var italica) heads. Journal of the Science and Food Agriculture 85: 1154-1160.

Costa, M.L., Civello, P.M., Chaves, A.R. \& Martínez, G.A. 2006. Hot air treatment decreases chlorophyll catabolism during postharvest senescence of broccoli (Brassica oleracea L. var. italica) heads. Journal of the Science of Food and Agriculture 86: 1125-1131.

Coupe, S.A., Sinclair, B.K., Greer, L.A., Gapper, N.E., Watson, L.M. \& Hurst P.L. 2003a. Analysis of acid invertase gene expression during the senescence of broccoli florets. Postharvest Biology and Technology 28: 27-37.

Coupe, S.A., Sinclair, B.K., Watson, L.M., Heyes, J.A. \& Eason J.R. 2003b. Identification of dehydration-responsive cysteine proteases during post-harvest senescence of broccoli florets. Journal of Experimental Botany 54: 1045-1056.

Da Silva, J.C., Donizeti Alves, J., Alves de Alvarenga, A., Murad Magalhaes, M., Einstein do Livramento, D. \& Deitos Fries D. 2003. Invertase and sucrose synthase activities in coffee plants sprayed with sucrose solution. Scientia Agricola 60: 239-244.

Downs, C.G., Somerfield, S.D. \& Davey, M.C. 1997. Cytokinin treatment delays senescence but not sucrose loss in harvested broccoli. Postharvest Biology and Technology 11:93-100.

Eason, J.R., Ryan, D.J., Watson, L.M., Pinkney, T., Hedderley, D., Christey, M.C., Braun, R.H. \& Coupe S.A. 2007. Suppresing expression of a soluble acid invertase (BoINV2) in broccoli (Brassica oleracea) delays postharvest floret senescence and downregulates cysteine protease (BoCP5) transcription. Physiologia Plantarum 130: 46-57.

Fan, X. \& Mattheis, J.P. 2000. Reduction of ethylene induced physiological disorders of carrots and iceberg lettuce by 1-methylcyclopropene. HortScience 35: 1312-1314.

Funamoto, Y., Yamauchi, N., Shigenaga, T.\& Shigyo M. 2002. Effects of heat treatment on chlorophyll degrading enzymes in stored broccoli (Brassica oleracea L.). Postharvest Biology and Technology 24: 163-170.

Gómez-Lobato, M.E., Hasperué, J.H., Civello, P.M., Chaves, A.R.\& Martínez G.A. 2012. Effect of 1-MCP on the expression of chlorophyll degrading genes during senescence of broccoli (Brassica oleracea L.). Scientia Horticulturae 144: 208-211.

Gong, Y. \& Mattheis J.P. 2003. Effect of ethylene and 1-methylcyclopropene on chlorophyll catabolism of broccoli florets. Plant Growth regulation 40: 33-38.

Hasperué, J.H., Chaves, A.R. \& Martínez, G.A. 2011. End of day harvest delays postharvest senescence of broccoli florets. Postharvest Biology and Technology 59: 64-70.

Hurst, P., Cheer, V., Sinclair,B. \& Irving D. 1996. Biochemical responses of asparagus to controlled atmosphere storage at $20^{\circ} \mathrm{C}$. Journal of Food Biochemistry 20: 463-472.

Itai, A. \& Tanahashi, T. 2008. Inhibition of sucrose loss during cold storage in japanese pear (PyruspyrifoliaNakai) by 1-MCP. Postharvest Biology and Technology 48: 355-363.

Jeffery, D., Smith, C., Goodenough, P., Prosser, I. \& Grierson, D. 1984. Ethylene-independent and ethylene-dependent biochemical changes in ripening tomatoes. Plant Physiology 74: 32-38. 
J. Hasperué et al. (2014) 23: 48-59

King, G.A. \& Morris, S.C. 1994. Early compositional changes during postharvest senescence of broccoli. Journal of the American Society for Horticultural Science 119: 1000-1005.

Koch, K.E. 1996. Carbohydrate-modulated gene expression in plants. Annual Review of Plant Biology 47: 509-540.

Lemoine, M.L., Civello, M., Martínez, G. \& Chaves, A.R. 2007. Influence of a postharvest UV-C treatment on refrigerated storage of minimally processed broccoli (Brassica oleracea var italica). Journal of the Science of Food and Agriculture 87: 1132-1139. Lichtenthaler, H.K. 1987. Chlorophylls and carotenoids: pigments of photosynthetic biomembranes. Methods in Enzymology 148 : 350-382.

Lu, Y., Gehan, J.P. \& Sharkey, T.D. 2005. Daylength and circadian effects on starch degradation and maltose metabolism. Plant Physiology 138: 2280-2291.

Makhlouf, J., Castaigne, F., Azul, J.,Willemot, C. \& Gosselin A. 1989. Long-term storage of broccoli under controlled atmosphere. HortScience 24: 322-328.

Martin, T., Frommer, W.B., Salanoubat, M. \&Willmitzer, L. 1993. Expression of an Arabidopsis sucrose synthase gene indicates a role in metabolization of sucrose both during phloem loading and in sink organs. The Plant Journal 4:367-377.

Martínez-Hernández, G.B., Artés-Hernández, F., Gómez, P., Formica, A.C. \& Artés, F. 2013. Combination of electrolysed water, UV-C and superatmospheric $\mathrm{O}_{2}$ packaging for improving fresh-cut broccoli quality. Postharvest Biology and Technology 76: 125-134.

McKenzie, M.J., Greer, L.A., Heyes, J.A. \& Hurst, P.L. 2004.Sugar metabolism and compartmentation in asparagus and broccoli during controlled atmosphere storage. Postharvest Biology and Technology 32: 45-56.

Miller,G.L. 1959. Use of dinitrosalicylic acid reagent for determination of reducing sugar. Analytical Chemistry 31: 426-428.

Mita, S., Suzuki-Fujii, K. \& Nakamura K. 1995.Sugar-inducible expression of a gene for beta-amylase in Arabidopsis thaliana. Plant Physiology 107: 895-904.

Muñoz, F.J., Baroja-Fernández, E., Morán-Zorzano, M.T., Viale, A.M., Etxeberria, E., Alonso-Casajús, N. \& Pozueta-Romero, J. 2005. Sucrose synthase controls both intracellular ADP glucose levels and transitory starch biosynthesis in source leaves. Plant Cell Physiology 46: 1366-1376.

Nägele, T., Henkel, S., Hörmiller, I., Sauter, T., Sawodny, O., Ederer, M. \& Heyer A. 2010. Mathematical modeling of the central carbohydrate metabolism in arabidopsis reveals a substantial regulatory influence of vacuolar invertase on whole plant carbon metabolism. Plant Physiology 153: 260-272.

Nakamura, K., Ohto M., Yoshida, N. \& Nakamura, K. 1991. Sucrose induced accumulation of P-amylase occurs concomitant with the accumulation of starch and sporamin in leaf-petiole cuttings of sweet potato. Plant Physiology 96: 902-909.

Nishikawa, F., Kato, M., Hyodo, H., Ikoma, Y., Sugiera, M. \& Yano M. 2005. Effect of sucrose on ascorbate level and expression of genes involved in the ascorbate biosynthesis and recycling pathway in harvested broccoli florets. Journal of Experimental Botany 56: 65-72.

Orzechowski, S. 2008. Starch metabolism in leaves. Acta Biochimica Polonica 55: 435-445.

Pogson, B.J. \& Morris, S.C. 1997.Consequences of cool storage of broccoli on physiological and biochemical changes and subsequent senescence at $20^{\circ} \mathrm{C}$. Journal of the American Society for the Horticultural Sciences 122: 553-558.

Pramanik, B.K., Matsui, T., Suzuki, H. \& Kosugi, Y. 2004. Changes in acid invertase activity and sugar distribution during postharvest senescence in broccoli. Pakistan Journal of Biological Sciences 7: 679-684

Pramanik, B.K., Matsui, T., Suzuki, H. \& Kosugi, Y. 2005. A sucrose synthase gene from broccoli: cDNA cloning, sequencing and its expression during storage. Biotechnology 4: 288-295.

Rodrigues, A.S. \& Rosa, E.A.S. 1999. Effect of post-harvest treatments on the level of glucosinolates in broccoli. Journal of the Science of Food and Agriculture 79: 1028-1032.

Sharma, R. \& Schopfer, P. 1987. Phytochrome-mediated regulation of $\beta$-amylase mRNA in mustard (Sinapsisalba L.) cotyledons. Planta 171: 313-320.

Singh, M.B. \& Knox, R.B. 1984. Invertases of liliumpollen. Characterization and activity during in vitro germination. Plant Physiology 74: 510-515.

Smith, S.M., Fulton, D.C., Chia, T., Thorneycroft, D., Chapple, A., Dunstan, H., Hylton, C., Zeeman, S.C. \& Smith A.M. 2004. Diurnal changes in the transcriptome encoding enzymes of starch metabolism provide evidence for both transcriptional and posttranscriptional regulation of starch metabolism in arabidopsis leaves. Plant Physiology 136: 2687-2699.

Sowokinos, J., Lulai, E.C. \& Knoper, J.A. 1985. Translucent tissue defects in Solanum tuberosum L. Plant Physiology 78: 489-494.

Sturm, A. \& Chrispeels, M.J. 1990. cDNA cloning of carrot extracellular $\beta$-fructosidase and its expression in response to wounding and bacterial infection. The Plant Cell 2: 1107-1119.

Suthumachai, W., Matsui, T., Kawada, K. \& Kosugi Y. 2006.Changes in acid invertase activity and sugar contents in lettuce during storage at ambient temperature. Asian Journal of Plant Science 5: 304-310.

Suzuki, Y., Asoda, T., Matsumoto, Y., Terai, H. \& Kato M. 2005. Suppression of the expression of genes encoding ethylene biosynthetic enzymes in harvested broccoli with high temperature treatment. Postharvest Biology and Technology 36: 265-271.

Tian, M., Talebul, I., Stevenson, D. \& Irving, D. 1997. Color, ethylene production, respiration, and compositional changes in broccoli dipped in hot water. Journal of the American Society for Horticultural Science 122: 112-116.

Wang, F., Sanz, A., Brenner, M.L., \& Smith, A. 1993. Sucrose synthase, starch accumulation, and tomato fruit sink strength. Plant Physiology 101:321-327. 
Wind.J., Smeekens, S., Hanson, J. 2010. Sucrose: metabolite and signaling molecule. Phytochemistry 71: 1610-1614.

Yu, T.S., Zeeman, S.C., Thorneycroft, D., Fulton, D.C., Dunstan, H., Lue, W.L., Hegemann, B., Tung, S.Y., Umemoto, T., Chapple, A., Tsai, D.L., Wang, S.M., Smith, A.M., Chen, J., \&Smith, S.M. 2005. $\alpha$-Amylase is not required for breakdown of transitory starch in arabidopsis leaves. The Journal of Biological Chemistry 280: 9773-9779.

Zaicovski, C.B., Zimmerman, T., Nora, L., Roos Nora, F., Silva, J.A., \& Rombaldi, C.V. 2008. Water stress increases cytokinin biosynthesis and delays postharvest yellowing of broccoli florets. Postharvest Biology and Technology 49: 436-439.

Zeeman, S.C., Smith, S.M., \& Smith, A.M. 2007. The diurnal metabolism of leaf starch. Biochemical Journal 401: 13-28. 